\title{
Stem cells in toxicological research
}

\author{
Hermann M. Bolt ${ }^{1}$
}

Received: 9 November 2017 / Accepted: 13 November 2017 / Published online: 15 November 2017

c) Springer-Verlag GmbH Germany, part of Springer Nature 2017

Large efforts have been invested to improve in vitro systems with stem cells for toxicity testing (Liu et al. 2017; Godoy et al. 2013, 2016; Chen et al. 2017; Cheng et al. 2016; Hammad 2013; Hammad et al. 2017). This field of research is of high interest, since it offers the perspective of an unlimited supply of all relevant human cell types that can be applied for in vitro toxicity tests (Leist et al. 2017). Research efforts have focused particularly on stem cell-derived cardiomyocyte and hepatocyte like cells and on developmental toxicity as well as developmental neurotoxicity (Waldmann et al. 2017; Shinde et al. 2015, 2016; Meganathan et al. 2015). Standardized protocols are available that allow the generation of beating cardiomyocytes derived from embryonic or induced pluripotent stem cells (Sirenko et al. 2017). This offers the possibility to study whether test compounds compromise rhythmic beating patterns of the cells (Chaudhari et al. 2017). In the field of hepatocyte research, it has become possible to generate hepatocyte-like cells from human embryonic stem cells as well as pluripotent stem cells (Godoy et al. 2015). These hepatocyte-like cells adopt several features of primary hepatocytes, e.g. secretion of albumin and formation of bile canaliculi. It has, however, become clear that there are also major differences compared to primary hepatocytes. For example, stem cell-derived hepatocyte-like cells adopt unwanted features, such as the expression of colon-specific genes and remaining stemless (Godoy et al. 2015).

For developmental toxicity testing, stem cells are allowed to differentiate to neuronal precursor cells (Shinde et al. 2015; Colaianna et al. 2017). Chemicals are added during the differentiation period to test whether this process is disturbed (Pallocca et al. 2016; Rempel et al. 2015). Such approaches led to the establishment of the developmental toxicity index, which quantifies the fraction of genes

Hermann M. Bolt

bolt@ifado.de

1 IfADo-Leibniz Research Centre for Working Environment and Human Factors at TU Dortmund, Ardeystr. 67,

44139 Dortmund, Germany involved in normal differentiation whose expression is compromised by the test chemicals (Shinde et al. 2017). Despite progress in the establishment of reliable in vitro systems and convincing case studies with small numbers of compounds the novel human stem cell-derived test systems have not yet been introduced into toxicological routine. A major limitation is a lack of comprehensive validation studies including sufficient numbers of positive and negative control compounds. It will be interesting to learn with which accuracy the new test systems predict human toxicity.

\section{References}

Chaudhari U, Nemade H, Sureshkumar P et al (2017) Functional cardiotoxicity assessment of cosmetic compounds using humaninduced pluripotent stem cell-derived cardiomyocytes. Arch Toxicol Sep 22. https://doi.org/10.1007/s00204-017-2065-z (Epub ahead of print)

Chen X, Han T, Fisher JE et al (2017) Transcriptomics analysis of early embryonic stem cell differentiation under osteoblast culture conditions: Applications for detection of developmental toxicity. Reprod Toxicol 69:75-83. https://doi.org/10.1016/j. reprotox.2017.02.001

Cheng W, Zhou R, Liang F, Wei H, Feng Y, Wang Y (2016) Application of Mouse Embryonic Stem Cell Test to Detect GenderSpecific Effect of Chemicals: A Supplementary Tool for Embryotoxicity Prediction. Chem Res Toxicol 29(9):1519-1533

Colaianna M, Ilmjärv S, Peterson H et al (2017) Fingerprinting of neurotoxic compounds using a mouse embryonic stem cell dual luminescence reporter assay. Arch Toxicol 91(1):365-391

Godoy P, Hewitt NJ, Albrecht U et al (2013) Recent advances in 2D and $3 \mathrm{D}$ in vitro systems using primary hepatocytes, alternative hepatocyte sources and non-parenchymal liver cells and their use in investigating mechanisms of hepatotoxicity, cell signaling and ADME. Arch Toxicol 87(8):1315-530

Godoy P, Schmidt-Heck W, Natarajan K et al (2015) Gene networks and transcription factor motifs defining the differentiation of stem cells into hepatocyte-like cells. J Hepatol 63(4):934-942. doi: 10.1016/j.jhep.2015.05.013. Erratum in: J Hepatol. 2016, 64(2):525-526

Godoy P, Widera A, Schmidt-Heck W et al (2016) Gene network activity in cultivated primary hepatocytes is highly similar to diseased mammalian liver tissue. Arch Toxicol 90(10):2513-2529 
Grinberg M, Stöber RM, Edlund K et al (2014) Toxicogenomics directory of chemically exposed human hepatocytes. Arch Toxicol 88(12):2261-2287

Hammad S (2013) Advances in 2D and 3D in vitro systems for hepatotoxicity testing. EXCLI J 12:993-996

Hammad S, Abdel-Wareth AAA, El-Sayed YS (2017) In vitro-in vivo correlation: hepatotoxicity testings. J Exp Appl Anim Sci [S.l.], v. 1, n. 3, p. 384-387, March 2016. ISSN 2314-5692. Available at: http://www.m-sciences.com/index.php?journal=jeaas\&page $=$ ar ticle\&op=view\&path $\% 5 \mathrm{~B} \% 5 \mathrm{D}=1066$. https://doi.org/10.20454/ jeaas.2015.1066

Leist M, Ghallab A, Graepel R et al (2017) Adverse outcome pathways: opportunities, limitations and open questions. Arch Toxicol Oct 19. doi: https://doi.org/10.1007/s00204-017-2045-3 (Epub ahead of print)

Liu S, Yin N, Faiola F (2017) Prospects and frontiers of stem cell toxicology. Stem Cells Dev 26(21):1528-1539. https://doi. org $/ 10.1089 / \mathrm{scd} .2017 .0150$

Meganathan K, Jagtap S, Srinivasan SP, Wagh V, Hescheler J, Hengstler J, Leist M, Sachinidis A (2015) Neuronal developmental gene and miRNA signatures induced by histone deacetylase inhibitors in human embryonic stem cells. Cell Death Dis 6:e1756

Pallocca G, Grinberg M, Henry M, Frickey T, Hengstler JG, Waldmann T, Sachinidis A, Rahnenführer J, Leist M (2016) Identification of transcriptome signatures and biomarkers specific for potential developmental toxicants inhibiting human neural crest cell migration. Arch Toxicol 90(1):159-180

Rempel E, Hoelting L, Waldmann T et al (2015) A transcriptome-based classifier to identify developmental toxicants by stem cell testing: design, validation and optimization for histone deacetylase inhibitors. Arch Toxicol 89(9):1599-1618

Shinde V, Klima S, Sureshkumar PS et al (2015) Human pluripotent stem cell based developmental toxicity assays for chemical safety screening and systems biology data generation. J Vis Exp 100:e52333

Shinde V, Perumal Srinivasan S, Henry M et al (2016) Comparison of a teratogenic transcriptome-based predictive test based on human embryonic versus inducible pluripotent stem cells. Stem Cell Res Ther 7(1): 190

Shinde V, Hoelting L, Srinivasan SP et al (2017) Definition of transcriptome-based indices for quantitative characterization of chemically disturbed stem cell development: introduction of the STOP-Tox $_{\mathrm{ukn}}$ and STOP-Tox ${ }_{\mathrm{ukk}}$ tests. Arch Toxicol 91(2):839-864

Sirenko O, Grimm FA, Ryan KR et al (2017) In vitro cardiotoxicity assessment of environmental chemicals using an organotypic human induced pluripotent stem cell-derived model. Toxicol Appl Pharmacol 322:60-74

Waldmann T, Grinberg M, König A et al (2017) Stem cell transcriptome responses and corresponding biomarkers that indicate the transition from adaptive responses to cytotoxicity. Chem Res Toxicol 30(4):905-922 